\title{
СТРУКТУРНІ ФОНДИ В СИСТЕМІ ЄВРОРЕГІОНАЛЬНОГО ВИРІВНЮВАННЯ
}

\section{STRUCTURAL FUNDS IN THE EURO REGIONAL ALIGNMENT SYSTEM}

\author{
Редьква Оксана Зіновіївна \\ кандидат економічних наук, \\ Тернопілььський національний технічний університет імені Івана Пулюя \\ ORCID: https://orcid.org/0000-0002-8246-4305 \\ Цеханович Віктор Борисович \\ аспірант, \\ Луганський національний університет імені Тараса Шевченка \\ ORCID: https://orcid.org/0000-0001-7199-8558 \\ Redkva Oksana \\ Ternopil Ivan Puluj National Technical University \\ Tsekhanovych Viktor \\ Luhansk Taras Shevchenko National University
}

\begin{abstract}
Стаття присвячена актуальним питанням використання можливостей фрінансування проектів проблемних районів у єврорегіонах Україна - ЄС, європейськими структурними фондами, якими на даний момент є "Фонд згуртування», «Європейський фонд регіонального розвитку», "Європейський соціальний фронд". Все це пов'язано з постійною адаптацією з реформуванням інститутів спільного фрінансування розвитку проблемних єврорегіонів. Проаналізовано діяльність структурних фондів, яка сприймається неоднозначно, маючи як прихильників так і опонентів. Досліджено напрямки усунення диспропорційності єврорегіонального розвитку. Доведено, що найбільш ефективним інструментом державного впливу на розвиток регіону $є$ фонди регіонального розвитку. Виокремлено основні фрункції агенцій регіонального розвитку, через які відбудеться зменшення рівня безробіття, інфляяції та підтримка слаборозвинених регіонів.
\end{abstract}

Ключові слова: структурні фонди, транскордонний дисбаланс, єврорегіональне вирівнювання, євроінтеграційні процеси, регіональна політика, агенції регіонального розвитку.

Статья посвящена актуальным вопросам использования возможностей финансирования проектов проблемных районов в еврорегионах Украина - ЕС, европейскими структурными фрондами, которым на данный момент является "Фонд сплочения», «Европейский фонд регионального развития», «Европейский социальный фронд". Все это связано с постоянным адаптацией с реформированием институтов совместного фринансирования развития проблемных еврорегионов. Проанализирована деятельность структурных фрондов, которая воспринимается неоднозначно, имея как сторонников так и оппонентов. Исследовано направления устранения диспропорции еврорегионального развития. Доказано, что наиболее эффективным инструментом государственного влияния на развитие региона являются фронды регионального развития. Выделены основные функции агентств регионального развития, через которые произойдет уменьшение уровня безработицы, инорляции и поддержка слаборазвитых регионов.

Ключевые слова: структурные фронды, трансграничный дисбаланс, еврорегиональное выравнивания, евроинтеграционные процессы, региональная политика, агентства регионального развития.

The acquisition by the Ukrainian economy of innovative development features entails corresponding shifts in the priority areas of alignment of Euro-regional activities. The article is devoted to current issues of using the opportunities for financing projects of problem areas in the Ukraine-EU Euro regions, European structural funds, which at the moment is the "Cohesion Fund", "European Regional Development Fund", "European Social Fund". All this is associated with the constant adaptation and harmonization of forms and standards of management of development projects of EU countries, reforming the institutions of co-financing the development of problem Euro regions. Analyzes the activities of structural funds that are perceived ambiguously, having both supporters and opponents. This is due to the fact 
that most regions on both sides of the border are characterized by different levels of development and structure of the economic complex, the predominance or absence of agglomeration, the degree of development of transport communications, and socio-economic problems. The directions of eliminating the imbalance of Euro regional development are investigated. It is proved that the most effective tool of state influence on the development of the region are the funds of regional development. The main thing is the task of which is to accumulate funds to finance cross-border co-production activities. The main functions of regional development agencies, through which unemployment, inflation and support for underdeveloped regions will be reduced, are highlighted. Reducing regional differences and supporting Euro regions are the EU's strategic goals, which are based on economic integration, leading to a single market that is designed to ensure the free movement of people, capital, goods and services. Solving the problem of alignment of the country's regions potentially it will have a synergistic effect. This effect will apply to almost everything aspects of the life of the country and society, will determine the conditions for sustainable social development economic development, as well as human and social development. Non-interference in these processes can lead to the aggravation of regional imbalances, since its most likely result may be the concentration of the most competitive sectors of the economy in some regions and the concentration of economic backwardness in others.

Keywords: structural funds, cross-border imbalance, Euro regional alignment, European integration processes, regional policy, regional development agencies.

Постановка проблеми. Політика регіонального вирівнювання за своєю природою $€$ найбільш складним вираженням солідарності країн ЄС. Це пов'язано насамперед з фрінансуванням структурних регіональних орондів у бюджеті $€ \mathrm{C}$, різноманітністю та змістом проектів транскордонного співробітництва, а також реалізованих за фрінансової підтримки даних фрондів. Політика вирівнювання єврорегіональної діяльності приносить користь всім громадянам з боку кордону, найчастіше через місцеві та регіональні влади, яким доручено керувати регіональним розвитком.

У той же час, важливого внеску політики в державні інвестиції та досягнення цілей розвитку, викладених у різних стратегіях $€ C$, може бути недостатньо, щоб забезпечити амбіції сталого і збалансованого розвитку всіх єврорегіонів Україна-ЄС, їх економічної рівності, і вирішити проблему адаптації регіонів до геополітичних, соціально-економічних, технологічних та екологічних змін.

Аналіз останніх досліджень. Визначенню теоретико-методологічних засад виникнення диспропорцій регіонального розвитку, аналізу транскордонних дисбалансів та фрормуванню механізмів регулювання нерівномірностей розвитку адміністративно-територіальних одиниць присвячено наукові праці С. Білої, Л. Возної, М. Деркача, О. Дудкіної, О. Дейнеки, М. Долішнього, Т. Пепи, Ю. Підлипного, Т. Синиці, Л. Сімків, І. Сторонянської, О. Фанюк, І. Хаджинова, О. Шевченка та ін.

Враховуючи досвід не вивчення проблематики диспропорційності єврорегіонального розвитку вітчизняними вченими, на сьогоднішній день чи мало питань щодо визначення конкретних напрямів усунення диспропорцій та вибору програми фрінансового вирівнювання розвитку єврорегіонів залишаються не вирішеними.
Мета статті. Метою статті є дослідження діяльності структурних фоондів та визначення їх впливу на політику системи єврорегіонального вирівнювання. Дана мета зумовлює виконання таких завдань: виявлення кращих європейських фракторів структурних фрондів $€ C$ та впровадження їх механізмів у систему єврорегіонального вирівнювання в Україні.

Основні результати дослідження. Європейська регіональна політика почала фрормуватися разом 3 розвитком європейської інтеграції. Державна регіональна політика $€$ частиною соціально-економічної політики, та є системою цілей, завдань, принципів, а також організаційних, правових та економічних заходів та інструментів, що визначаються і використовуються державними органами в галузі регулювання соціально-економічного розвитку регіонів країни.

Європейський тип взаємодії регіонів заснований на безпосередніх контактах кожного регіону з великою групою як своїх національних, швидкими темпами розширюється до $€ C$. Для них вже не є перешкодою традиційні державні кордони. У підсумку державні кордони для громад, округів, провінцій, земель стають непомітними або прозорими.

3 метою реалізації спільних проектів регіони сприяють розвитку двостороннього і багатостороннього взаємного прикордонного співробітництва. Вони мають право самостійно або спільно з іншими регіонами відкривати свої представництва в інших державах і у відповідних міжнародних організаціях. Якщо зневажаються повноваження або інтереси регіонів, вони беруть участь у міжнародній діяльності своїх держав, керуючись своїм внутрішнім законодавством.

Досягнення збалансованого розвитку у єврорегіонах вимагає проведення ефективної 
державної регіональної політики, спрямованої на подолання нерівномірностей розвитку адміністративно-територіальних одиниць 3 урахуванням специфріки економічного розвитку кожного окремого регіону. Диореренціація регіонального розвитку формується під впливом таких фракторів, як: наявність природних ресурсів (їх склад та масштаби), природнокліматичні умови, географрічне розташування (центр/периферія, прикордонна територія), історичні та демограсрічні особливості (кількість та вікова структура населення), господарська спеціалізація, стан інсрраструктури, політичні фрактори (законодавчі обмеження чи пресреренції розвитку окремих регіонів), склад та структура людського капіталу (наявність висококваліфікованих кадрів, рівень освіти), інноваційне середовище, агломерація, урбанізаційні процеси та ін. [1, с. 44; 2].

Одним 3 основних елементів функціонування єврорегіонів $€$ економічна складова, яка має принципове значення. Економічна складова охоплює проблеми економічного вирівнювання суміжних територій, питання фрінансування проєктів прикордонного співробітництва, передбачає спільний пошук шляхів подолання бар'єрів, що стоять на шляху учасників зовнішньоекономічної діяльності, стимулювання процесу фрормування та активізації зовнішньоекономічних відносин бізнес-спільнот прикордонних територій.

Значна роль у вирівнюванні соціальноекономічного розвитку єврорегіонів належить бюджетні політиці, оскільки вона визначає розмір коштів, що спрямовуються на здійснення наднаціонального регулювання. Бюджетна політика - ключовий інструмент макроекономічної політики, що покликана підтримувати стабільне зростання, протидіяти кризам та інорляції, а також забезпечувати високу ступінь зайнятості людських ресурсів. Загальний бюджет $€ \subset$ є унікальним спільним проектом великої кількості країн, які об'єднали свої ресурси для вирішення спільних завдань.

Структурні фронди спочатку, ще при їх фрормуванні, головним чином, були спрямовані на вирівнювання регіональних і соціальних диспропорцій в ЄС. У теоретичному обґрунтуванні, запропонованому для розподілу фрондів, міститься питання про такі проблеми, як нездатність деяких держав (регіонів) виправити свої внутрішні економічні дисбаланси і той фракт, що фрінансування на рівні $€$ б буде набагато більш координовано і організовано. Крім того, було висловлено припущення про те, що інтегративний процес породить подальші диспропорції через наступні фрактори - ефректу масштабу; агломерація; локалізації економічної активності в економічно розвинених регіонах; виборчої міграції робочої сили з бідніших до економічно розвинених регіонів [3].

Структурні фонди дозволяють регіонам отримувати додаткові ресурси для стимулювання розвитку, зменшення рівня безробіття, активізації інвестиційної діяльності. При цьому скорочується залежність країн-членів $€ С$ від фрінансових ресурсів національних урядів, що дає підстави говорити про ЄС як про «Європу регіонів». Координація регіонального розвитку єдиного європейського центру дозволяє впроваджувати та підтримувати на відсталих територіях передові напрями регіональної політики. "Європа регіонів" передбачає розвиток співпраці 3 регіонами інших країн 3 мінімальним втручанням центру (наприклад, Польща).

3 прийняттям стратегії до 2027 року для досягнення мети забезпечення економічного розвитку і вирівнювання в ЄС створені і продовжують працювати три основні фронди:

1. Європейський фронд регіонального розвитку. Даний фонд був створений на підставі Постанови ЄС № 1080/2006 Європейського парламенту і ради від 5 липня 2006 року [4]. Головним завданням даного фонду $\epsilon$ розробка програм щодо зменшення диспропорцій у розвитку різних регіонів $Є С$, розвиток депресивних регіонів, посилення конкурентоспроможності. Стосовно до програми "Європа 2020" діяльність даного фонду повинна зосередитися на чотирьох пріоритетах:

- інновації та дослідження;

- розвиток цифррових технологій;

- підтримка малих і середніх підприємств;

- зниження парникового есректу.

Ресурси 3 цього фронду не обов'язково можуть використовуватися на ці чотири цілі. Але країни повинні дотримуватися певних правил. Так в групі розвинених країн не менше 80\% витрачається на два пріоритети з чотирьох, а в малорозвинених менше $50 \%$.

2. Європейський соціальний фронд. Спрямований на сприяння зайнятості, соціальній інтеграції та інвестиціями в людський капітал у сорері освіти та професійної підготовки. За допомогою даного фонду $Є С$ здійснює досягнення цілей по боротьбі з бідністю. На даний момент, основна мета європейських структурних та інвестиційних фрондів полягає у сприянні сталому соціально-економічному зближенню, стабільності та територіальної згуртованості регіонів $€ С$ [5]. Основними цілями $€$ : 
- адаптація працівників і підприємств (впровадження схем безперервної освіти, створення і розширення інноваційних організацій працівників);

- доступ до зайнятості для шукачів роботи, безробітних, жінок і мігрантів;

- соціальна інтеграція людей, що знаходяться в несприятливих умовах, і боротьба 3 дискримінацією на ринку праці;

- зміцнення людського капіталу шляхом реформування системи освіти та створення мережі навчальних закладів.

Європейський соціальний фронд $€$ основним фрінансовим інструментом у Європі для підтримки робочих місць, діяльність якого спрямована на допомогу людям 3 питань отримання кращої роботи і забезпечення справедливих робочих місць для всіх громадян ЄС. Він працює за рахунок інвестицій в людський капітал Європи - своїх працівників, своїх молодих людей і всіх тих, хто шукає роботу. ESF фрінансує 10 млрд. євро на рік на поліпшення перспективи працевлаштування для мільйонів європейців, зокрема тих, яким важко отримати роботу. Європейська Комісія та країни ЄС у партнерстві встановлюють пріоритети ESF та визначають порядок витрат його ресурсів. Одним 3 пріоритетів $є$ підвищення адаптивності працівників 3 новими навичками, і підприємств з новими методами роботи. Інші пріоритети спрямовані на створення умов для зайнятості: допомагаючи молодим людям зробити перехід від школи до роботи, навчання або менш кваліфрікованої роботи, щоб поліпшити свої перспективи працевлаштування. Дійсно, професійна підготовка і безперервне навчання для отримання нових навичок складають значну частину багатьох проектів Європейського соціального фонду.

ESF повинен сприяти: високому рівню зайнятості та якості роботи, покращувати доступ до ринку праці, підтримувати географрічну та прооресійну мобільність працівників, сприяти їх адаптації до промислових змін, змін у виробничих системах, необхідних для сталого розвитку, заохочувати високий рівень освіта, навчання, здійснювати підтримку переходу між освітою та працевлаштуванням молоді, боротьба з бідністю, посилення соціальної інтеграції та сприяння гендерній рівності, недискримінації та рівним можливостям, вносячи тим самим внесок у пріоритети Союзу щодо зміцнення економічних, соціальних і територіальних згуртованостей.

3. Європейський фонд розвитку. Покриває потреби країн нових членів ЄС, займається розвитком трансєвропейської логістики та проектами в галузі енергетики. В галузі охорони навколишнього середовища даний фонд підтримує інвестиції в адаптацію до змін клімату та запобігання ризикам, а також інвестиції в сектор водопостачання, каналізації, та розвиток міського середовища, підтримує інвестиції в енергетичному секторі, за умови, що вони матимуть позитивний вплив на навколишнє середовище. 3 цієї причини будуть підтримуватимуться інвестиції в підвищення енергоефективності відновлюваних джерел, а також буде надаватись допомога у надзвичайних ситуаціях (наприклад постійних підтопленнях в єврорегіоні "Нижній Дунай").

Фонд покликаний забезпечити швидку, еорективну та гнучку надзвичайну фінансову допомогу для таких заходів, як надання тимчасового житла або тимчасовий ремонт життєво важливої інорраструктури, що дозволяє відновити повсякденне життя.

Допомога фонду розвитку ЄС приймає форму єдиного та глобального гранту, що доповнює суспільні зусилля держави-членабенесріціара. Фонд призначений для фрінансування наступних заходів:

- негайне відновлення в робочому стані інфрраструктури та установок в галузі енергетики, питної води, стічних вод, транспорту, телекомунікацій, охорони здоров'я та освіти;

- надання тимчасового розміщення та екстрених служб для задоволення нагальних потреб населення;

- негайне забезпечення превентивної інорраструктури та заходів з охорони культурної спадщини;

- очищення територій, постраждалих від стихійних лих, у тому числі природних зон.

Постійні стихійні лиха спонукали державичлени переглянути свої потреби в галузі розвитку. У цьому відношенні технічне коригування бюджету ЄC забезпечить додаткові фрінансові кошти для ряду держав-членів і проблемних регіонів.

Можна стверджувати, що для ефрективного використання ресурсів Фонду розвитку необхідне фрормування сучасної і чітко фрункціонуючої адміністрації. Велике значення має також діюча інституційна система, відповідальна за використання ресурсів ЄС.

Викликом інтеграції у сорері ефективного використання коштів Фонду згуртування $\epsilon$ зменшення юридичних бар'єрів, які стосуються публічних та бюджетних фонансів. Складними і забюрократизованими залишаються також вимоги, пов'язані 3 охороною навколишнього середовища. 
Для ефрективного фрункціонування фонду розвитку ЄС важлива ефрективно фрункціонуюча система інформаційного забезпечення процесів обґрунтування, реалізації та контролю проектів, що фрінансуються за рахунок коштів Фонду, система контролю та недопущення маніпуляцій у сорері отримання, використання структурних ресурсів.

У транспортній сфрері, в доповненні до інвестицій у Транс-Європейські транспортні мережі (TEN-T) фронд розвитку буде підтримувати інвестиції в транспортні системи з низьким вмістом вуглецю і міський транспорт.

Таким чином, фоонд розвитку $€$ основним інструментом $€ С$ щодо сприяння комплексного територіального розвитку в єврорегіонах, рівень розвитку яких нижчий середньоєвропейського.

Мета Фонду полягає в тому, щоб доповнити зусилля відповідних держав і покрити частину їх державних витрат, з тим щоб допомогти відповідній державі здійснити, в залежності від виду прийнятного лиха або надзвичайної ситуації, наступні основні надзвичайні та відновлювальні операції:

- відновлення працездатності об'єктів інсрраструктури та установок у ссрерах енергетики, водопостачання та водовідведення, телекомунікацій, транспорту, охорони здоров'я та освіти;

- надання тимчасового житла та фрінансування рятувальних служб для задоволення потреб відповідного населення;

- забезпечення превентивної інфрраструктури та заходів з охорони культурної спадщини;

- очищення постраждалих від стихійних лих районів, включаючи природні зони, відповідно, де це доречно, з екосистемними підходами, а також негайне відновлення постраждалих природних зон, щоб уникнути негайних наслідків ерозії ґрунтів;

- заходи, спрямовані на оперативне надання допомоги, в тому числі медичної, населенню, постраждалому в результаті великої надзвичайної ситуації в галузі суспільної охорони здоров'я, і на захист населення від ризику бути порушеним, включаючи профрілактику, моніторинг або контроль поширення захворювань, боротьбу з серйозними ризиками для здоров'я населення або пом'якшення їх впливу на здоров'я населення [5].

У 2021-2027 роках фронд зближення надаватиме підтримку у фрормі інвестування, в наступних пріоритетних напрямках [5]:

1."Розумна" Європа - через інновації, цисрровізацію, економічні перетворення та підтримку малого та середнього бізнесу.
2. Більш екологічна, безвуглецева Європа, яка реалізує Паризьку угоду та інвестує в енергетичний перехід, відновлювані джерела енергії та боротьбу зі зміною клімату.

3.Більш взаємопов'язана Європа зі стратегічними транспортними та цифровими мережами.

4. Більш соціальна Європа, що реалізує Європейський стовп соціальних прав і підтримує якісну зайнятість, освіту, навички, соціальну інтеграцію і рівний доступ до охорони здоров'я.

Так, у бюджеті $€ \subset$ на період з 2021 по 2027 роки на дані програми фонду виділено 330235 млн. євро, серед яких на транскордонне співробітництво та впровадження регіональних інновацій по 500 млн. євро на кожен проєкт.

Активізація євроінтеграційних процесів в Україні викликає необхідність ресрормування фрондів, удосконалення механізмів реалізації та інструментарної політики $€ C$, удосконалення ії цілей і завдань. Подальша інтеграція не змінила базових цілей політики $€ \subset$, яка полягала в скороченні розриву між регіонами в рівнях розвитку для посилення економічного і соціального згуртування. У зв'язку з цим широко вживаним стало поняття «політика згуртування», яке передбачає сприяння гармонійному розвитку ЄС на основі створення умов для економічного і соціального зближення регіонів і країн-членів. Така політика базується на необхідності згуртування нових членів $€ C$ після розширення. ЄС повинен докладати зусиль до згуртування і досягнення єдиного економічного простору на всій території ЄС в результаті приєднання нових країн [6].

Як ми бачимо результати використання структурних фоондів ЄС, особливо в останні роки, дають підставу вважати, що єврорегіони Україна-ЄС в цілому досить есрективно рухаються до досягнення цілей фрункціонування, домагаються істотного прогресу в їх досягненні.

Вкладені інвестиції забезпечують конкретні поліпшення в житті людей єврорегіонів, особливо - в його проблемних регіонах, в таких ключових областях, як економічний розвиток, зайнятість, охорона здоров'я, доступність послуг, охорона навколишнього середовища, а також надають можливість досить оперативно реагувати на виникаючі потреби, такі як криза міграції.

Збереження підтримки у всіх регіонах $€$, включаючи більш розвинені, вважається найбільш ефективним способом вирішення міжсекторальних проблем: Глобалізація та економічні перетворення, перехід до низьковуглецевої та циркулярної економіки, еколо- 
гічні проблеми, міграція та осередки міської бідності, знаком солідарності та способом забезпечення.

Як ми бачимо вирівнювання в єврорегіонах через структурні фонди дають наступні результати:

1. Зниження бар'єрів у русі національних ресурсів і сракторів виробництва.

2. Формування громадських благ у еврорегіонах (розвиток транспортної, енергетичної, сільськогоссподарської інфрраструктури).

3.Зменшення «провалів» ринку регіональної динаміки економічного простору (сировинний «експансії» одних регіонів, по відношенню до інших, монополізації регіональних ринків і т. д.).

4. зниження «провалів» держави до єврорегіонального розвитку (розвиток інтеграції ринків, торгівлі, освіти, реалізація транскордонного потенціалу регіонів і т. д.).

5. Підвищення конкурентоспроможності, інвестиційності та інноваційності розвитку єврорегіонів.

6. Врегулювання можливих територіальних розбіжностей як полігон для апробації сумісності правових, митних, економічних, соціокультурних систем у єврорегіонах.

Що стосується України то в даний момент йде розробка програми регіонального розвитку на 2021-2027 роки.

В Україні можна виділити дві складові в діяльності загальнодержавних і місцевих органів влади, що стосуються механізмів вирівнювання в єврорегіонах.

Перша-адміністративно-правове регулювання процесів взаємодії центру та регіонів, а також адміністрацій виконавчої влади та місцевих органів влади. Для подолання стану депресивності територій необхідно запровадити відповідні програми, які розроблятимуться центральними та місцевими органами виконавчої влади.

Другою складовою механізму регіонального вирівнювання є перерозподіл орінансових ресурсів та проведення фрінансової підтримки, зокрема, малих підприємств 3 використанням бюджетних та позабюджетних інструментів. Використовуючи фрінансові ресурси, держава надає допомогу непрацездатним, безробітним та іншим категоріям населення, які потребують соціального захисту. Важливу роль у вирівнюванні економічного рівня розвитку регіонів відіграє Державна податкова і кредитна політики, субсидії, дотації.

Зважене поєднання фрінансового вирівнювання відсталих регіонів і одночасна моти- вація розвитку найбільш перспективних адміністративно-територіальних одиниць $\epsilon$ важливим завданням державної регіональної політики в подоланні диспропорций регіонального розвитку, адже нехтування показниками розвитку високорозвинених регіонів або штучне їх наближення до слаборозвиненим неминуче призводить до погіршення соціально-економічних показників усіх регіонів (розвинені регіони виступають своєрідними фрінансовими «донорами» малорозвинених).

Вирівнювання В єврорегіонах України залежно від їх характеру - має, як правило, має декілька фрорм:

1. Фізична допомога: інвестиції для підвищення інвестиційної привабливості регіону/ території, покращення фрізичного середовища, відновлення зон загального користування, занедбаних будівель тощо.

2. Ділова інфрраструктура (парки, бізнеспослуги (консультації, підтримка, бізнес-інкубатори тощо), підтримка інновацій (як правило, з огляду на необхідність диверсифрікації для забезпечення виробництва продукції 3 більш високою додатковою вартістю).

3 Соціальна допомога - покращення соціальної інсрраструктури, якості життя.

4 Заходи на ринку праці - субсидії у зв'язку 3 безробіттям тощо, навчання безробітних або осіб, яким загрожує безробіття.

5 Фінансові стимули (або еквівалентні заходи) для підприємств або інноваційних бізнес-проектів 3 метою забезпечення інвестиційної підтримки. Замість надання фрінансової допомоги, доцільніше забезпечувати субсидії для надання послуг підтримки бізнесу (у формі інсрормаційного забезпечення, консультацій, інструктажу з питань бізнес-планування тощо) та спрощувати адміністративні бар'єри ведення бізнесу.

Для вирівнювання діяльності в регіонах (єврорегіонах) України було створено Агентство регіонального розвитку. Його робота регулюється ст. 19 Закону України "Про засади державної регіональної політики" [7] та Постановою КМУ «Про затвердження типового положення про агенцію регіонального розвитку».

У відповідності до статті 19 Закону, Агенства регіонального розвитку:

Співзасновниками агенцій регіонального розвитку також можуть бути регіональні торгово-промислові палати, регіональні асоціації підприємців, регіональні представництва всеукраїнських асоціацій органів місцевого самоврядування чи асоціації органів місцевого самоврядування регіону, вищі навчальні 
заклади, наукові установи, профільні громадські об'єднання регіону.

Вони будуть виконувати такі фрункції:

1) проведення аналізу соціально-економічної ситуації, проблем розвитку відповідного регіону, та подання міським держадміністраціям пропозицій щодо шляхів їх розв'язання;

2) вивчення досвіду інших держав щодо реалізації регіональної політики та підготовка пропозицій щодо використання позитивного досвіду в регіоні;

3) сприяння, у тому числі шляхом організації та проведення консультаційної роботи, у: реалізації суб'єктами регіонального розвитку регіональної стратегії розвитку та виконанні плану заходів з її реалізації, програм і проєктів регіонального розвитку; підвищенні інвестиційної привабливості регіону, залученні інвестиційних та кредитних ресурсів, міжнародної технічної допомоги для регіонального розвитку; створенні умов для інституційного та інфрраструктурного розвитку регіону;

4) участь у: проведенні моніторингу стану виконання у регіоні завдань, визначених Державною стратегією регіонального розвитку, плану заходів з реалізації регіональної стратегії розвитку, програм і проектів регіонального розвитку; розробленні пропозицій щодо правового регулювання питань регіонального розвитку;

5) інфрормування громадськості про діяльність агенції, зокрема шляхом розміщення на своєму офріційному веб-сайті відповідної інфрормації та в інший прийнятний спосіб.

Реалізація цих фуункцій зобов'язує АРP виступати одночасно в чотирьох ролях: посередника з інвестиційної діяльності; координатора процесу розвитку території; консалтингової установи; центру підтримки та розвитку бізнесу.
Достатньо чітке визначення завдань і фрункцій в Положенні про агенцію регіонального розвитку на рівні області дозволяє сорормувати високоефективну інституційноорганізаційну структуру АРP. Разом з тим, за умов фрормування інституційно-організаційної структури, адекватної поставленим завданням і стартовим можливостям АРР, становлення ії спроможності $€$ дуже повільним.

На основі вищезазначеного можна зробити висновок, що одним з найбільш динамічних, еластичних та ефективних інструментів державного впливу на їх розвиток $€$ фронди регіонального розвитку, головне завдання яких - акумулювати кошти для фрінансування транскордонної спільної виробничої діяльності. Неоднозначне ставлення до структурних фондів, пов'язано з тим, що для більшості регіонів по обидва боки кордону характерні різні рівні розвитку та структура господарського комплексу, переважання або відсутність агломерації, ступінь розвитку транспортних комунікацій та соціально-економічні проблеми. Зменшення регіональних відмінностей та підтримка єврорегіонів - стратегічні цілі $€ C$, які базуються на економічній інтеграції, що веде до створення єдиного ринку, призначеного для забезпечення вільного руху людей, капіталу, товарів та послуг. Невтручання у ці процеси може призвести до погіршення регіональних дисбалансів, оскільки його найбільш вірогідним результатом може бути концентрація найбільш конкурентоспроможних секторів економіки в одних регіонах та концентрація економічної відсталості в інших. Крім того, специфрікою інтеграційної Асоціації $€$ підвищення рівня економічного розвитку по всій Асоціації через зменшення рівня безробіття та інфрляції в результаті підтримки слаборозвинених регіонів.

\section{СПИСОК ВИКОРИСТАНИХ ДЖЕРЕЛ:}

1. Раєвнєва О.В., Бобкова О.Ю. Диспропорційність соціально-економічного розвитку регіонів України: інструментарій оцінювання та регулювання : монограсрія. Харків, 2014.

2. Кизим М.О., Мощицька Т.О. Дослідження міжрегіональних диспропорцій соціально-економічного розвитку в Україні. Проблеми економіки. 2011. № 2. С. 36-39. Режим доступу: https://www.problecon.com/annotatedcatalogue/?year=2011\&abstract=2011_02_0

3. Report from the commission to the european parliament, the council, the european economic and social committee and the committee of the regions strategic report 2017 on the implementationn of the european structural and investment funds, brussels (2017). Strategic report 2017 on the implementation of the European Structural and Investment Funds. Retrieved from: https://ec.europa.eu/regional_policy/sources/docoffic/official/reports/strat_ rep_2017/strat_rep_2017_en.pdf

4. Regulation (EC) No 1080/2006 of the European Parliament and of the Council of 5 July 2006 on the European Regional Development Fund and repealing Regulation (EC) No 1783/1999 (2010). Retrieved from: https://eur-lex.europa.eu/legal-content/EN/ALL/?uri=CELEX\%3A32006R1080 
5. Козирєва О. В., Тур О. В. Політика вирівнювання соціально-економічного розвитку регіонів в Європейському Союзі. Бізнесінформ. 2016. № 9. Режим доступу: https://www.business-inform.net/annotated-catalogue/? year=2016\&abstract=2016_09_0\&lang=ua\&stqa=4

6. 2021-2027 long-term EU budget \& Next Generation EU (н.д.). Режим доступу: https://ec.europa.eu/info/ strategy/eu-budget/long-term-eu-budget/eu-budget-2021-2027_en

7. Закон України «Про засади державної регіональної політики» 05.02.2012 р. № 156-VIII. Законодавство України. Режим доступу: https://zakon.rada.gov.ua/laws/show/156-19\#Text

8. Постанова КМУ «Про затвердження Типового положення про агенцію регіонального розвитку» : Постанова від 11 лютого 2016 р. № 258. Законодавство України. Режим доступу: https://www.kmu.gov.ua/npas/ 248941325

\section{REFERENCES:}

1. Raievnieva O.V., Bobkova O.lu. (2014). Dysproportsiinist sotsialno-ekonomichnoho rozvytku rehioniv Ukrainy: instrumentarii otsiniuvannia ta rehuliuvannia [Disproportion of socio-economic development of Ukrainian regions: toolkit, evaluation and regulation]. Kharkiv. (in Ukrainian)

2. Kyzym M.O., Moshchytska T.O. (2011). Doslidzhennia mizhrehionalnykh dysproportsii sotsialno-ekonomichnoho rozvytku $v$ Ukraini [The research of inter-regional imbalances of socio-economic development in Ukraine]. Problemy ekonomiky, 2, 36-39. Retrieved from: https://www.problecon.com/annotated-catalogue/?year=2011\& abstract=2011_02_0

3. Report from the commission to the european parliament, the council, the european economic and social committee and the committee of the regions strategic report 2017 on the implementationn of the european structural and investment funds, brussels (2017). Strategic report 2017 on the implementation of the European Structural and Investment Funds. Retrieved from: https://ec.europa.eu/regional_policy/sources/docoffic/official/reports/ strat_rep_2017/strat_rep_2017_en.pdf

4. Regulation (EC) No 1080/2006 of the European Parliament and of the Council of 5 July 2006 on the European Regional Development Fund and repealing Regulation (EC) No 1783/1999 (2010) (n.d.). Retrieved from: https://eur-lex.europa.eu/legal-content/EN/ALL/?uri=CELEX\%3A32006R1080

5. Kozyrieva O. V., Tur O. V. (2016). Polityka vyrivniuvannia sotsialno-ekonomichnoho rozvytku rehioniv $v$ Yevropeiskomu Soiuzi [The policy of alignment of socio-economic development of regions in the European Union. Biznesinform, 9. (in Ukrainian)

6. 2021-2027 long-term EU budget \& Next Generation EU (n.d.). Retrieved from: https://ec.europa.eu/info/ strategy/eu-budget/long-term-eu-budget/eu-budget-2021-2027_en

7. Zakon Ukrainy «Pro zasady derzhavnoi rehionalnoi polityky» 05.02 .2012 r. № 156-VIII. Zakonodavstvo Ukrainy [Law of Ukraine «On Principles of State Regional Policy». № 156-VIII. Legislation of Ukraine. Retrieved from: https://zakon.rada.gov.ua/laws/show/156-19\#Text

8. Postanova KMU «Pro zatverdzhennia Typovoho polozhennia pro ahentsiiu rehionalnoho rozvytku»: Postanova vid 11 liutoho 2016 r. № 258 [Resolution of the Cabinet of Ministers of Ukraine «On approval of the Standard Regulations on the Regional Development Agency»] № 258. Legislation of Ukraine. Retrieved from: https://www.kmu.gov.ua/npas/248941325 